\title{
Bioaccumulation of Metals in the Organs of Fish inhabiting Ravi River: Serious Threat to Fish and Consumer's Health
}

\author{
Zarish Yaqoob $^{1}$, Saleema Bashir Shams ${ }^{2}$, Gaitee Joshua ${ }^{2}$ and Bibi Nazia Murtaza ${ }^{2,3 *}$ \\ ${ }^{1}$ Department of Environmental Sciences, Kinnaird College for Women, 93-Jail Road, \\ Lahore 54000 \\ ${ }^{2}$ Department of Zoology, Kinnaird College for Women, 93-Jail Road, Lahore 54000 \\ ${ }^{3}$ Abbottabad University of Science and Technology, Abbottabad
}

\begin{abstract}
A B S T RA C T
Heavy metal contamination of river water adversely affects the growth and productivity of fish and contributes to the human health disasters. River is a trans-country river originating in Himachal Pradesh, India and joins Indus and its tributary rivers in the Punjab province of Pakistan. The present study describes the concentration of heavy metals in the water and different tissues of native fish collected from three different areas. The highest concentration of $\mathrm{Cr}(1.451$ $\left.\mu \mathrm{g} \mathrm{L}^{-1}\right)$ and $\mathrm{Co}(0.325 \mu \mathrm{g} \mathrm{L}-1)$ was measured in the river water at Balloki. However, Cd $\left(0.981 \mu \mathrm{g} \mathrm{L}^{-1}\right)$ and $\mathrm{Zn}(1.239$ $\mu \mathrm{g} \mathrm{L}^{-1}$ ) were contributing maximum contamination at confluence of Deg Nallah and river Ravi. We found maximum accumulation of $\mathrm{Cr}(21.1 \mathrm{ppm})$ in Rita rita, $\mathrm{Co}(13.1 \mathrm{ppm})$ in Channa marulius, $\mathrm{Cd}(20.1 \mathrm{ppm})$ in Cirrhinus mrigala and $\mathrm{Zn}(32.9 \mathrm{ppm})$ in Cyprinus carpio. Maximum accumulation of heavy metals was found in the gills of fish followed by liver, kidneys, muscle and fat cells. Overall, seventeen fish species were recorded in the study areas indicating a decrease in the number of species in Ravi. The results have shown that the water of Ravi is unsafe for aquatic life and irrigation. Metal concentration in the fish meat is higher than the recommended dietary allowance (RDA) parameters indicating a serious health threat to both, the fish and human population.
\end{abstract}

\begin{tabular}{l} 
Article Information \\
\hline Received 05 May 2018 \\
Revised 30 July 2018 \\
Accepted 10 April 2019 \\
Available online 13 August 2020 \\
Authors' Contribution \\
SBS and GJ designed the study \\
plan, ZY, SBS and GJ collected the \\
field samples and performed the lab \\
experiments. BNM composed and \\
revised the manuscript and analyzed \\
the data. \\
Key words \\
Water pollution, fish, heavy metals, \\
human health, Ravi
\end{tabular}

\section{INTRODUCTION}

$\mathrm{H}$ eavy metals are non-biodegradable elements contributing very long-lasting type of pollutants (Ukoha et al., 2014; Sthanadar et al., 2015). Industrial and municipal wastes are the major anthropogenic sources for heavy metal accumulation in the fresh water ecosystems. The subsequent accumulation of heavy metals in aquatic organisms can badly adulterate the food chains. These can also affect the growth and reproduction rate of living organisms (Vosylien and Jankaite, 2006; Hayat et al., 2007). Fish provide an indicative factor for the assessment of water systems, especially for the estimation of quality and suitability of water for the living organisms (Mahboob et al., 2016). Fresh water fish and shellfish accumulates the higher concentrations of metals than the corresponding water and sediments (Al-Weher, 2008; Mahboob et al., 2014). The bioaccumulation of metals depends upon the nature of metals and fish species (Twari-Fufeyin and Ekaye, 2007). Metal ions enter the fish body trough exposed epidermal surface or skin, gills and the food tract. Metal accumulation is higher

\footnotetext{
* Corresponding author: nazia.murtaza@gmail.com 0030-9923/2020/0006-2027 \$ 9.00/0

Copyright 2020 Zoological Society of Pakistan
}

in the kidneys and liver as compared to the fish muscle (Al-Ghanim et al., 2016; Milanov et al., 2016). Fish remains a key component of human diet comprising all the essential amino acids and fatty acids which reduce the risk of heart diseases (Kuz'mina, 2011). However, the metal toxicity in the fish meat can have serious impact on human health because of their cytotoxic, mutagenic and carcinogenic properties (Rauf et al., 2009; Ahmed et al., 2016). In addition to that the heavy metal stress reduces feed intake and productivity of fish (Sfakianakis et al., 2015).

Indus and its tributary rivers provide the basis for the largest canal system in Pakistan, vastly supporting the agricultural and livestock practices in the region. Ravi River is approximately $720 \mathrm{~km}$ long, $320 \mathrm{~km}$ of the river's length and most of water is used within India after the Indus Water Treaty (Hayder et al., 2015). The fluctuation of flow rate contribute to pollution and many other management problems. The main sources of pollution in the river Ravi stretching from Lahore Siphon to Balloki headworks are urban, agricultural and industrial wastewaters discharged from various industries like electroplating workshops, steel factories, paper and pulp industries, medicine and scientific laboratories, as well as surface runoff and municipal sewage. Many pumping stations discharging municipal sewage of Lahore city into the Ravi adding to the accumulation of toxic substance and metals in water. 
Present study deals with the estimation of heavy metal concentration in the water and in the tissues of fish species of Ravi River.

\section{MATERIALS AND METHODS}

\section{Study area}

The study area included three points i.e. Balloki area, Chenab near Balloki and at the confluence point of Ravi and Chenab. The sites were Ravi Siphon and Balloki Headwork reservoirs at the River Ravi, it's almost 60 $\mathrm{Km}$ Southwest for the collection of naturally occurring freshwater fish species (Fig. 1).

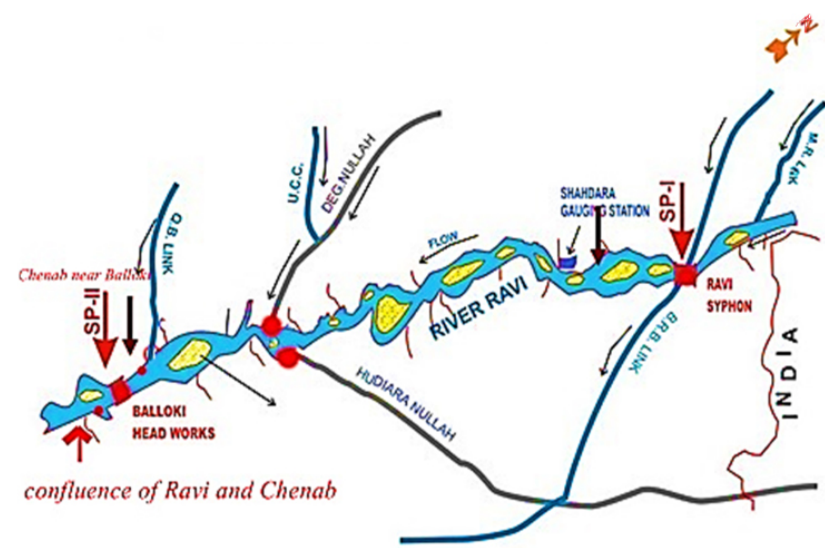

Fig. 1. Study areas, sample collection sites on river Ravi.

\section{Sample collection and initial analysis}

Samples were collected on 14th November 2016 and 31st March 2017 from Ravi siphon and the pond areas which was an offshoot of flood at Balloki headworks. Samples were also obtained from the river Ravi at Balloki headworks as well as from the confluence of Ravi and Chenab Rivers. Water samples were taken from two major drains on river Ravi i.e. Deghnallah and Hudiaranallah. Fish samples were stored in zip lock plastic bags and were kept in ice box for transportation. Samples were dried in filter paper, packed in polyethylene bags and kept in the freezer at $-20^{\circ} \mathrm{C}$ until evaluation. Temperature and $\mathrm{pH}$ of water was determined for each water sample and the water of fish sampling site. The coordinates of the study area were taken by using the GPS available in the smart phones. Standard identification key by (Mirza and Sandhu, 2007) was used to identify the fish species. The total length of each fish was measured from the tip of snout to longest ray in fish caudal fin by measuring scale. Number of annuli (rings) was counted which provides the fish age, all fish were weighed.

\section{Digestion method for water samples}

Nitric acid $(10 \mathrm{ml})$ was added in $100 \mathrm{ml}$ of water sample and boiled slowly till the sample volume decreased to $20 \mathrm{ml}$. The solution was cooled, $5 \mathrm{ml}$ of nitric acid was added and heated again to leave $5 \mathrm{ml}$ solution followed by the addition of hydrochloric acid. Heated the solution and $5 \mathrm{ml}$ of $5 \mathrm{M}$ Sodium hydroxide was added, then filtered. Filtrate was transferred to $100 \mathrm{ml}$ volumetric flask and distilled water was added up to $100 \mathrm{ml}$. The final sample was subjected to metal detection process.

\section{Preparation of tissue sample}

Stock solution of $1000 \mathrm{ppm}$ was prepared for all selective heavy metals. Fish organs such as gills, liver, kidney, muscle and fat cells were dissected and homogenized at $-20^{\circ} \mathrm{C}$ for heavy metal detection. A standard protocol for heavy metal analysis was adopted (Yousufzai et al., 2010).

\section{Estimation of heavy metals}

The concentrations of metals $(\mathrm{Cd}, \mathrm{Co}, \mathrm{Zn}$ and $\mathrm{Cr})$ were determined in the fish organs/tissues and water samples using Atomic Absorption Spectrometer (Analyst 800, Perkin Elmer, Massachusetts, USA) as described in the literature (Hashim et al., 2014). The concentration of chromium $(\mathrm{Cr})$, cadmium $(\mathrm{Cd})$, zinc $(\mathrm{Zn})$, and cobalt $(\mathrm{Co})$ in the fish tissues and water. Analytical grade chemicals were used.

\section{Statistical analysis}

Data obtained were expressed as mean \pm SE. The results were analyzed using one-way analysis of variances (ANOVA). Statistical version 8.1 was used. $P$ values $<0.05$ were considered statistically significant.

\section{RESULTS AND DISCUSSION}

There was no marked difference between the temperatures of all study areas at Ravi Siphon, average temperature was $26^{\circ} \mathrm{C}$. The $\mathrm{pH}$ of water at Hudiara was 8.3, with an annual discharge of 180 cusecs approximately, this drain is one of the major causes of bio-chemical contamination in Ravi (Table I). Zinc concentration in water was dependent positively and significantly on water temperature. Temperature change may decrease or increase toxicity, which depends on the toxicant plus species. According to the $\mathrm{pH}$ of Balloki and DegNala was slightly acidic. 
Table I.- Temperature, $\mathrm{pH}$ and heavy metal concentration in the river water $\left(\mu \mathrm{g} \mathrm{L}^{-1}\right)$ as measured from different areas in the passage of Ravi river.

\begin{tabular}{|c|c|c|c|c|c|c|c|}
\hline Sr. No. & Study areas & $\mathrm{Cr}(\mathrm{ppm})$ & Co (ppm) & Cd (ppm) & Zn (ppm) & Tesmperature & $\mathbf{p H}$ \\
\hline 1 & Ravi Siphon & 0.144 & 0.015 & 0.115 & 0.135 & $26^{\circ} \mathrm{C}$ & 7.0 \\
\hline 2 & Balloki headworks & 1.451 & 0.255 & 0.325 & 0.355 & $25^{\circ} \mathrm{C}$ & 6.5 \\
\hline 3 & Chenab near Balloki & 0.169 & ND & 0.112 & 0.212 & $27^{\circ} \mathrm{C}$ & 6.0 \\
\hline 4 & Confluence of Ravi and Chenab & 1.266 & ND & 0.122 & 0.132 & $27^{\circ} \mathrm{C}$ & 6.5 \\
\hline 5 & DegNallah before entering into river Ravi & 1.115 & 0.081 & 0.981 & 1.239 & $26^{\circ} \mathrm{C}$ & 5.7 \\
\hline 6 & Confluence of DegNallah and River Ravi & 1.015 & 0.012 & 0.123 & 1.038 & $25^{\circ} \mathrm{C}$ & 6.5 \\
\hline 7 & Hudiara-Nallah before entering into River Ravi & 1.092 & 0.061 & 0.111 & 1.044 & $27^{\circ} \mathrm{C}$ & 7.0 \\
\hline 8 & Confluence of Hudiara-Nallah and River Ravi & 1.029 & 0.013 & 0.017 & 1.021 & $26^{\circ} \mathrm{C}$ & 6.0 \\
\hline
\end{tabular}

However, that of Ravi Siphon was slightly basic and rest of the areas had neutral $\mathrm{pH}$. Pakistan's soil is almost dry and has a higher concentration of calcium carbonate but low organic matter content, this higher level of lime stone makes Pakistani soil more alkaline with $\mathrm{pH}$ near 8 or above. Concentration of $\mathrm{Cr}$ in water was highest in Ravi at Balloki (1.451 $\left.\mu \mathrm{g} \mathrm{L}^{-1}\right)$ followed by the Confluence point of Ravi and Chenab near Balloki, it was however lowest at Ravi Siphon. This is because of the industrial effluents poured into the river water from Hudiara and Degnallah. Although the water of Chenab and Ravi Siphon is comparatively cleaner and has a diluting effect, the concentration of $\mathrm{Cr}$ in Balloki is so high that there is very little change in its concentration at the Confluence of Ravi and Chenab. Concentration of Chromium in all study sites was high as compared to the standards of EPA. The metal concentration was hazardously high at Balloki and in Confluence of Ravi and Chenab. The concentration of Co in water remained in the safe range at all the study sites except at Balloki. The concentration of $\mathrm{Cd}$ in the water was above the standard acceptable values of EPA and FAO as measured at all the study sites. However, the maximum concentration was measured in water samples obtained at Balloki. The concentration of Zinc in all the study areas was within the standard acceptable values set by both FAO and EPA. It was however, like $\mathrm{Cd}, \mathrm{Co}$, and $\mathrm{Cr}$ highest in Ravi at Balloki headworks and lowest at the confluence of Ravi and Chenab. Among all the sites studied, the highest concentration of metal in water was that of Chromium in Balloki headworks (1.451ppm) (Table I). Concentration $\left(\mu \mathrm{g} \mathrm{L}^{-1}\right)$ of heavy metals in Ravi Siphon water was $\mathrm{Cr}$ (0.144), Co (0.015), Cd (0.115) and Zn (0.135). Order of the metal concentration from higher to low in water of Ravi siphon was $\mathrm{Cr}>\mathrm{Zn}>\mathrm{Cd}>\mathrm{Co}$. The concentrations of $\mathrm{Cd}$ were higher compared to the FAO standard limit i.e. $<0.1$ but $\mathrm{Zn}$ concentration is less as compared to the FAO standard limit i.e. $7.8 \mu \mathrm{g} \mathrm{ml}^{-1}$ (Table II). The concentrations $\left(\mu \mathrm{g} \mathrm{L}^{-1}\right)$ of selective heavy metals were $\mathrm{Cr}$
(1.451), Co (0.255), Cd (0.325) and $\mathrm{Zn} \mathrm{(0.355)} \mathrm{in} \mathrm{water}$ of Balloki headworks. Order of the metal concentration in water of Balloki headworks was $\mathrm{Co}>\mathrm{Cd}>\mathrm{Zn}>\mathrm{Cr}$. The concentrations $\left(\mu \mathrm{g} \mathrm{L}^{-1}\right)$ of $\mathrm{Cd}$ and $\mathrm{Cr}$ was higher than the FAO permissible limit i.e. $<0.1$ and 0.29 , respectively and concentrations $\mu \mathrm{g} \mathrm{L}^{-1}$ of $\mathrm{Zn}$ and Co are less according to FAO permissible limits i.e. 7.8 and 1-5. Concentrations $(\mu \mathrm{g}$ $\left.\mathrm{L}^{-1}\right)$ of selective heavy metals were $\mathrm{Cr}(0.690), \mathrm{Co}(0.000)$, $\mathrm{Cd}(0.112)$ and $\mathrm{Zn}(0.212)$ in water of Chenab near Balloki. Order of the metal concentration in water of Chenab near Balloki was $\mathrm{Cr}>\mathrm{Zn}>\mathrm{Cd}>\mathrm{Co}$. The concentration ( $\mu \mathrm{g}$ $\left.\mathrm{L}^{-1}\right)$ of $\mathrm{Cd}$ was higher than the FAO standard limit i.e. $<$ 0.1 . Selective heavy metal concentrations $\left(\mu \mathrm{g} \mathrm{L}^{-1}\right)$ were $\mathrm{Cr}$ (1.266), Co (ND), Cd (0.122) and Zn (0.132) in water from the confluence of Ravi and Chenab. metal concentration in water from the area confluence of Ravi and Chenab was $\mathrm{Cr}$ $>\mathrm{Zn}>\mathrm{Cd}>\mathrm{Co}$. The concentration of $\mathrm{Cr}$ and $\mathrm{Cd}$ are higher as compare to the FAO standard limit i.e. $0.29 \mu \mathrm{g} \mathrm{L}^{-1}$ and $<0.1 \mu \mathrm{g} \mathrm{L}^{-1}$ showed the comparison of water concentration of study areas with heavy metal FAO permissible limits in fresh water, it clearly showed that the concentration of Chromium was high in Ballokiheadworks and in confluence of Ravi and Chenab thus, it showed that $\mathrm{Cr}$ concentration also exceeded the permissible limits set by EPA and FAO standard limits of heavy metals concentrations. The main sources of pollution in River Ravi are municipal sewage, scientific laboratories, paper and pulp industries, steel factories and electroplating workshops (Khan, 2011) the highest and lowest concentration of heavy metals in major drains of river Ravi, $\mathrm{Zn}$ concentration was higher before entering into the river Ravi because of the excessive pollution load in Nallah Deg. All the factories drain their waste in it and it becomes more polluted105 reported factories have been observed near Nallah Deg on Sheikhupura road Lahore Punjab Pakistan these factories mostly discharge effluents containing heavy metals such as $\mathrm{Zn}, \mathrm{Cd}$ and $\mathrm{Cr}$ into Deg. 
Table II.- Fish species found in the study areas.

\begin{tabular}{llll}
\hline Sr. No. & Fish species of Siphon & Fish species of Chenab near Balloki & Fish species of confluence of Ravi and Chenab \\
\hline 1 & Chanda nama & Chanda nama & Chanda nama \\
2 & Rita rita & Rita rita & Pseudeutropius atherinoides \\
3 & Channa marulius & Channa marulius & Channa marulius \\
4 & Hypophthalmichthys molitrix & Cirrhinus mrigala & Hypophthalmichthys molitrix \\
5 & Labeo rohita & Gudusia chapra & - \\
6 & Sperata sarwari & Pseudeutropius atherinoides & - \\
7 & Catla catla & Labeo nigripinnis & - \\
8 & Wallago attu & - & - \\
9 & Cyprinus carpio & - & - \\
10 & Cirrhinus mrigala & - & \\
\hline
\end{tabular}

Overall, 15 species were found in the investigated area. The number of species was maximum at Siphon.

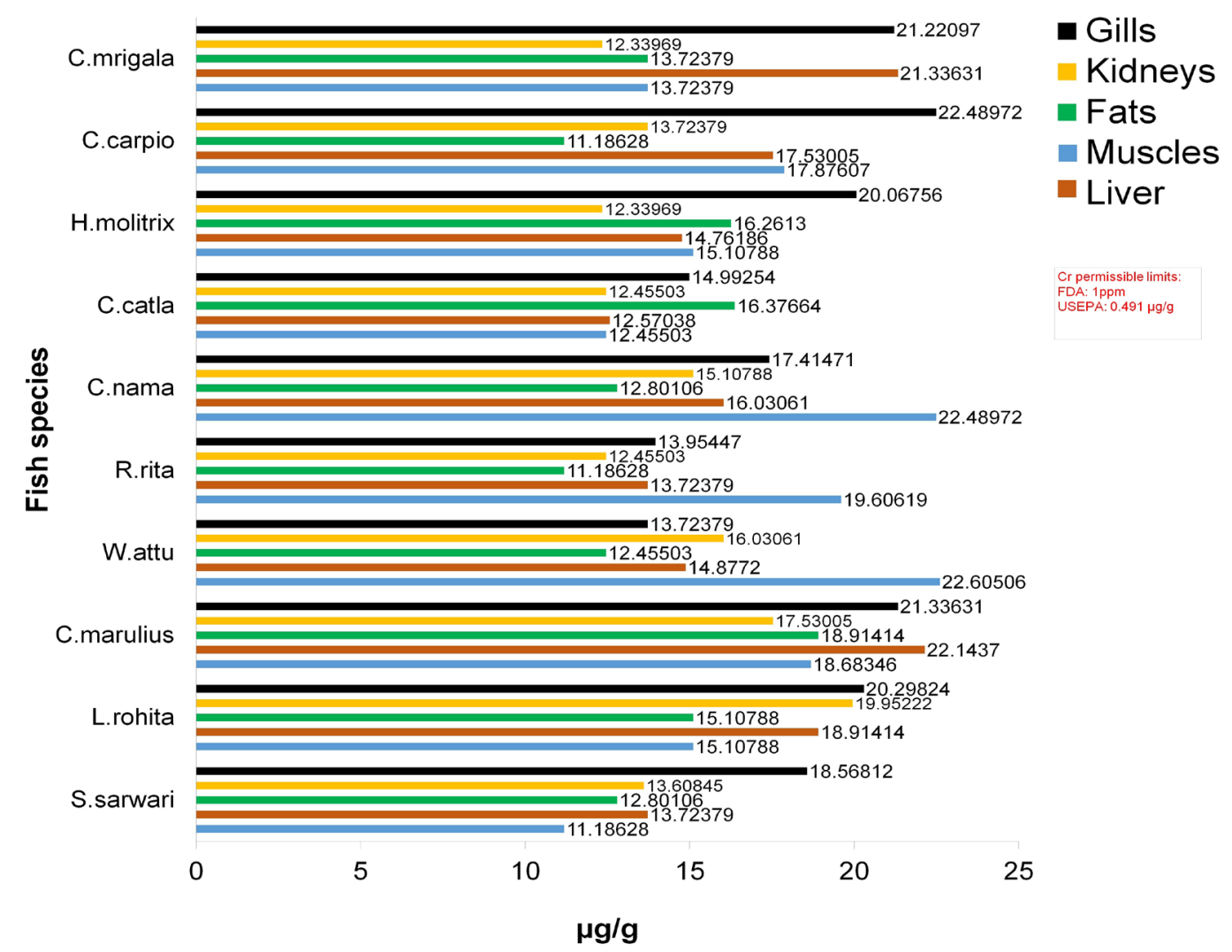

Fig. 2. $\mathrm{Cr}\left(\mu \mathrm{g} \mathrm{g}^{-1}\right)$ in different organs of different fish species from Ravi Siphon Lahore.

$\mathrm{Zn}$ is used in can food products for preservation of food in many countries because it is a non rusting compound (Rauf and Javed, 2007). Results showed that the concentrations $\mu \mathrm{g} / \mathrm{l}$ of $\mathrm{Zn} 1.021-1.239$ And $\mathrm{Cr}$ 1.015-1.115 are higher than Co: 0.012-0.081 and Cd .981-.017. Hudiara Nallah showed less concentration of heavy metals as compared to NallahDeg because it is flowing from river Ravi and carries pollution load of Ravi only.

Knowledge of heavy metal concentrations in fish is important with respect to nature of management and 
human consumption of fish. Bioaccumulation of metals in fish can be considered as an index of metal pollution in the aquatic bodies (Emmaneul et al., 2012). The fish samples collected from the River Ravi at Balloki showed a considerable drop in the number of fish collected from Ravi Siphon (Table II). Present results showed maximum accumulation in fish muscles and that is the part which is more eaten by humans whereas the rest is thrown away, other fish body tissues are used in production of chicken feed. In Pakistan $2 \mathrm{~kg}$ per year capita consumption and world's average per capita consumption is $17 \mathrm{~kg}$ per year. (Papagiannis et al., 2004). Fish diversity is higher in river Ravi Siphon because fish farming practices are less here because of the Pak army control and water conditions are also suitable for aquatic life pollution load is less in river Ravi Siphon. A study conducted by Emmaneul et al. (2012) found more medium tolerant specimens of macroinvertebrates as compared to tolerant ones. Balloki area showed more medium tolerant specimens as compared to tolerant ones but the presence of sensitive species then indicated much cleaner water as compared to the present study (Karadede and Unlu, 2007). Same study was conducted by Ather (Arther, 2015). Chlamydomonas, Chlorella and Volvox are the sensitive species whose number was quite low because of the polluted water Among the medium tolerant species are Cosmarium, Microsporia and Synedra. The diatoms species obtain from selective sampling sites were Pinnularia, Nitzchia and Navicula, all these diatoms species can survive in high polluted water environment (Javed, 2006). Euglena and Cosmarium are the species which can survive in high heavy metal deposited environment these all macro-invertebrates are the diet of Fish and this showed that due to polluted water and less availability of food for Fish can lead to shortage of Fish in river. Fish fry age was 1 month. Fish fry from river Ravi Siphon showed high level of $\mathrm{Zn}$ concentration in fish C. carpio that is $32.987 \mu \mathrm{g} / \mathrm{g}$ (Table III). In fish C. marulius high levels of $\mathrm{Zn}$ and $\mathrm{Cr}$ were identified,

Table III.- Metal accumulation in the tissues of fish species collected from Ravi River at different study areas.

\begin{tabular}{|c|c|c|c|c|c|c|c|c|}
\hline Sr. No. & Fish species found at Siphon & $\begin{array}{l}\text { Body } \\
\text { Weight (g) }\end{array}$ & $\begin{array}{l}\text { Body Length } \\
\text { (cm) }\end{array}$ & $\begin{array}{l}\text { Age of Fish } \\
\text { (years) }\end{array}$ & Cr ppm & Zn ppm & Cd ppm & Co ppm \\
\hline \multicolumn{9}{|c|}{ Fish species and associated parameters investigated in the present study at Ravi Siphon area } \\
\hline 1 & Sperata sarwari & 545.8 & 36.5 & 3 & 20.8 & 32.9 & 13.7 & 10.9 \\
\hline 2 & Labeo rohita & 487.9 & 34.5 & 3 & 16.5 & 21.1 & 20.1 & 12.9 \\
\hline 3 & Channa marulius & 456.3 & 36.0 & 4 & 21.1 & 20.1 & 12.8 & 10.9 \\
\hline 4 & Wallago attu & 567.9 & 40.5 & 3 & 18.6 & 21.9 & 10.9 & 13.1 \\
\hline 5 & Rita rita & 676.1 & 44.5 & 3 & 19.8 & 30.9 & 14.2 & 10.1 \\
\hline 6 & Chanda nama & 845.2 & 55.0 & 4 & 17.5 & 19.1 & 18.1 & 13.4 \\
\hline 7 & Catla catla & 662.8 & 49.7 & 4 & 20.1 & 18.3 & 15.7 & 14.9 \\
\hline 8 & Hypophthalmichthys molitrix & 560.8 & 52.9 & 3 & 18.1 & 20.2 & 11.9 & 15.2 \\
\hline 9 & Cyprinus carpio & 498.0 & 44.5 & 4 & 19.6 & 17.2 & 14.8 & 11.9 \\
\hline 10 & Cirrhinus mrigala & 575.9 & 53.2 & 4 & 16.6 & 19.7 & 12.9 & 13.8 \\
\hline \multicolumn{9}{|c|}{ Fish species and associated parameters investigated in the present study at Ravi near Balloki } \\
\hline 1 & Chanda nama & 558.9 & 44.3 & 3 & 32.8 & 30.9 & 29.7 & 11.9 \\
\hline 2 & Rita rita & 653.2 & 49.8 & 3 & 35.5 & 32.1 & 32.1 & 10.9 \\
\hline 3 & Channa marulius & 667.9 & 49.5 & 3 & 30.1 & 34.1 & 14.8 & 11.9 \\
\hline 4 & Cirrhinus mrigala & 587.1 & 42.0 & 3 & 18.1 & 20.2 & 11.9 & 15.2 \\
\hline 5 & Gudusia chapra & 782.5 & 60.5 & 5 & 19.6 & 17.2 & 14.8 & 11.9 \\
\hline 6 & Pseudeutropius atherinoides & 795.0 & 61.8 & 5 & 16.6 & 19.7 & 12.9 & 13.8 \\
\hline 7 & Labeo nigripinnis & 678.2 & 50.5 & 4 & 16.6 & 19.7 & 12.9 & 13.8 \\
\hline \multicolumn{9}{|c|}{ Fish species and associated parameters investigated from the confluence of Ravi and Chenab } \\
\hline 1 & Chanda nama & 458.3 & 34.0 & 3 & 21.2 & 20.3 & 13.8 & 11.9 \\
\hline 2 & Pseudeutropius atherinoides & 557.2 & 41.5 & 4 & 15.6 & 20.9 & 11.9 & 12.1 \\
\hline 3 & Channa marulius & 666.4 & 43.5 & 3 & 18.8 & 26.9 & 13.2 & 12.3 \\
\hline 4 & Hypophthalmichthys molitrix & 834.5 & 54.0 & 4 & 16.5 & 19.1 & 16.1 & 13.1 \\
\hline
\end{tabular}


its body wt (g) was 456.3, length (cm) of 36.0 and age 3 years Fish $H$. molitrix showed high $104.6 \mu \mathrm{g} / \mathrm{g} \mathrm{Cd}$ concentration with its body wt $(\mathrm{g}) 560.8$, length $(\mathrm{cm}) 52.9$ and age 4 years (Table III). Cr concentration in muscles, gills and in liver of fish species from Ravi siphon was low between $11.1 \mu \mathrm{g} / \mathrm{g}-22.6 \mu \mathrm{g} / \mathrm{g}$ (Fig. 2) as compare to other sampling sites like Balloki. In Siphon water order of $\mathrm{Cr}$ concentration in fish organs was this liver $>$ gills $>$ muscles $>$ kidneys $>$ fats that was $22.6 \mu \mathrm{g} / \mathrm{g}>22.4 \mu \mathrm{g} / \mathrm{g}>22.1 \mu \mathrm{g} / \mathrm{g}>$ $19.9 \mu \mathrm{g} / \mathrm{g}>18.9 \mu \mathrm{g} / \mathrm{g}$. Cr was high $22.6 \mu \mathrm{g} / \mathrm{g}$ in liver of fish $W$. attuandin liver of C. namai.e. $22.4 \mu \mathrm{g} / \mathrm{g}$ (Fig. 3) and its carnivorous fish which feed on small other fish that is why metal accumulated more in $W$. attu due to magnification. Order of $\mathrm{Cr}$ concentration in fats of different fish in water of river Siphon was C.carpio $>$ C.marulius $>$ C.mrigala $>L$. rohita $>$ H.molitrix Gills also showed high $22.4 \mu \mathrm{g} / \mathrm{g}$ concentrations of $\mathrm{Cr}$ in fish C.carpio. Heavy metal analysis of the whole fish specimens showed concentration for Chromium which showed an increase from fish fry stage to age 3 and age 4 . However, as muscles and fats are the only things most commonly and directly consumed by man. Concentration of $\mathrm{Cr}$ increased in the fish samples when compared with fish fry the complete sample fish fry of $C$. maruliusshowed a $\mathrm{Cr}$ concentration of $18.6 \mathrm{ppm}$ whereas only the muscles of this fish had $\mathrm{Cr}$. Concentration of 22.1437ppm and 18.914ppm was detected in fats of the same fish. Similarly, in all four species an increase was observed from fry stage to age 3 and 4 years. Results of Ravi Siphon (Fig. 3) showed that the concentration of $\mathrm{Zn}$ was higher between $45.5 \mu \mathrm{g} / \mathrm{g}-36.6 \mu \mathrm{g} / \mathrm{g}$ in fish muscles especially in fish $C$. carpio and $S$. sarwari. Increasing order of $\mathrm{Zn}$ concentration in different tissues of different fish species was this muscles $>$ liver $>$ kidneys $>$ fats $>$ gills ranged as $45.5 \mu \mathrm{g} / \mathrm{g}>32.6 \mu \mathrm{g} / \mathrm{g}>28.8 \mu \mathrm{g} / \mathrm{g}>22.4 \mu \mathrm{g} / \mathrm{g}$ $>20.0 \mu \mathrm{g} / \mathrm{g}$, respectively. Fish $C$. marulius showed maximum $276.5 \mu \mathrm{g} / \mathrm{g} \mathrm{Zn}$ concentration as compare to the other fish species of same area. $\mathrm{Zn}$ concentration in the whole fish fry was analyzed and compared with the

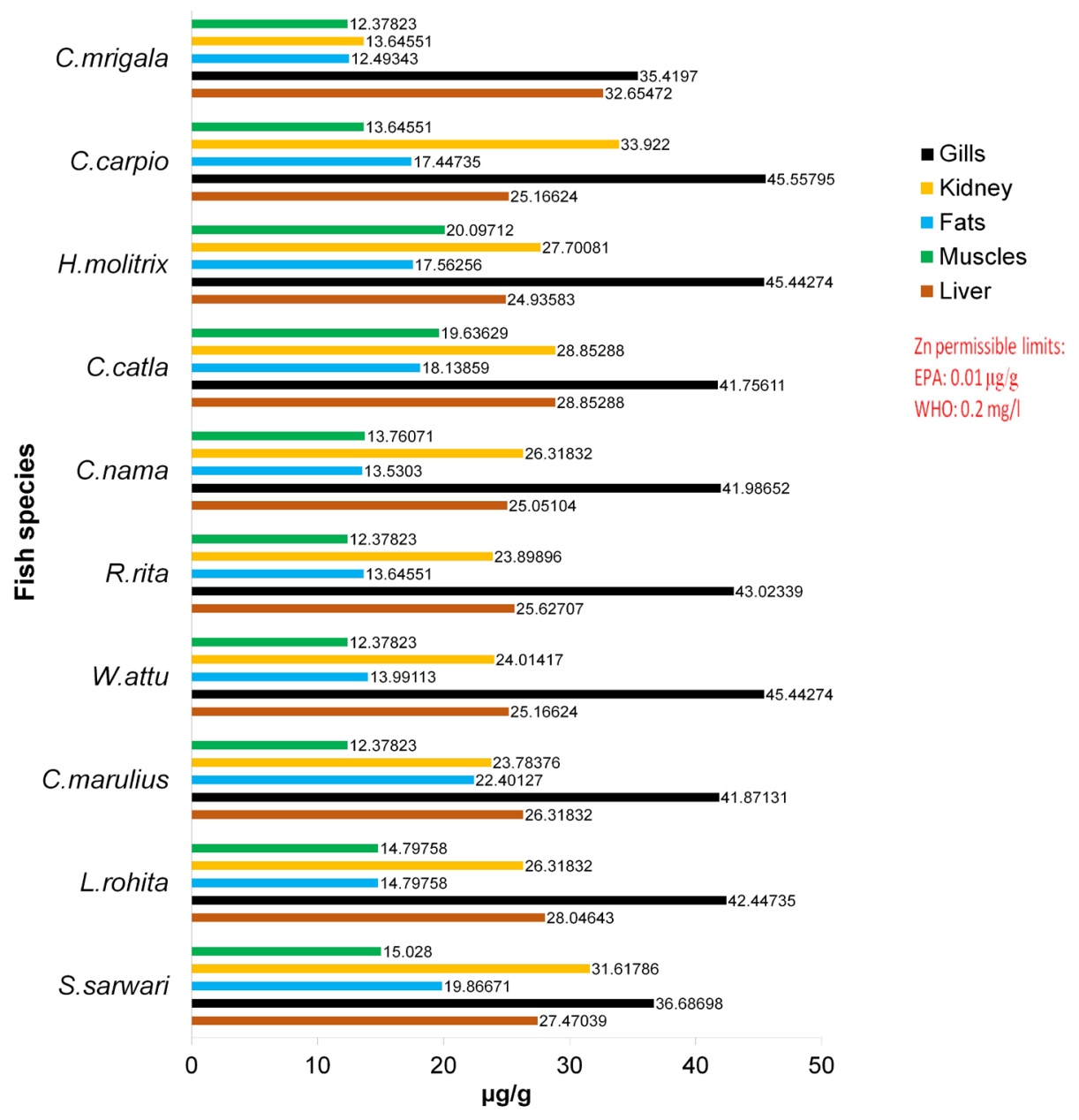

Fig. 3. $\mathrm{Zn}\left(\mu \mathrm{g} \mathrm{\textrm {g } ^ { - 1 }}\right)$ in different organs of different fish species from Ravi Siphon, Lahore. 


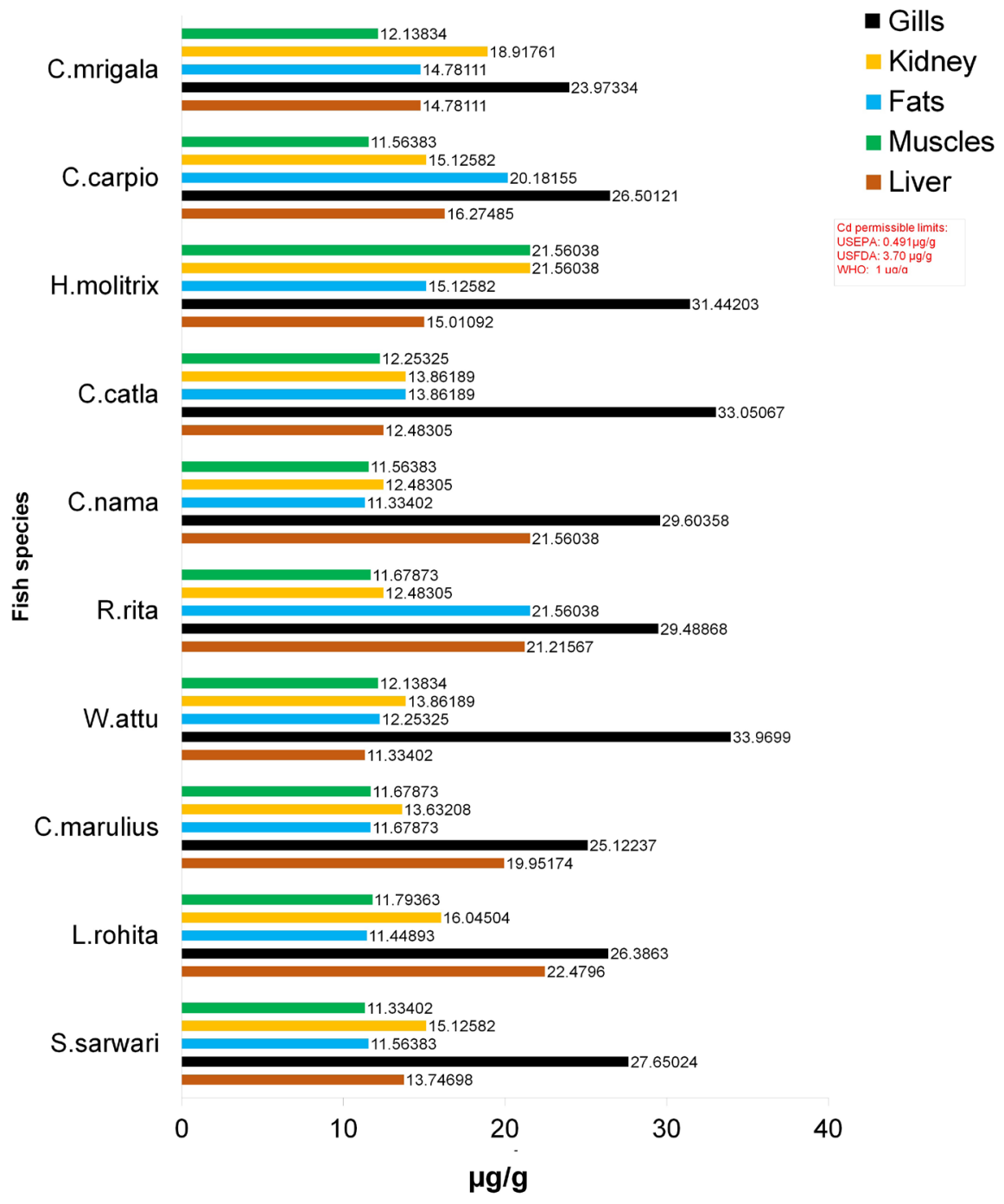

Fig. 4. $\mathrm{Cd}\left(\mu \mathrm{g} \mathrm{g}^{-1}\right)$ in different organs of different fish species from Ravi Siphon, Lahore.

concentration of $\mathrm{Zn}$ in the adult specimens of the same species at ages 3 and 4 years. All four fish studied showed a marked rise in $\mathrm{Zn}$ concentration even if only fish muscles were considered. All these readings were much higher than the acceptable standards for fish. The observed Cd levels in fish muscles collected from Ravi siphon showed high $33.9 \mu \mathrm{g} / \mathrm{g}$ concentration in muscles as compare to the other organs of same fish species were presented in (Fig. 4). $H$. molitrix showed high Cd concentration $104.6 \mu \mathrm{g} / \mathrm{g}$ among other fish species of Ravi Siphon. From all other fish tissues muscles accumulated more $\mathrm{Cd}$ in increasing order muscles $(33.9 \mu \mathrm{g} / \mathrm{g})>\operatorname{liver}(21.5 \mu \mathrm{g} / \mathrm{g})>$ fats $(20.1 \mu \mathrm{g} / \mathrm{g})>$ kidneys $(18.9 \mu \mathrm{g} / \mathrm{g})>$ gills $(12.5 \mu \mathrm{g} / \mathrm{g})$. C. marulius showed high level of $\mathrm{Zn}$ with its body weight (g) 350.2, body length $35.9(\mathrm{~cm})$ and age 3years. H. molitrix showed high levels of Cd and Cr with its body weight (g) 454.3, body length $32.5(\mathrm{~cm})$ and age 3 years. Results showed that metal accumulate and increase its concentration in fish tissues as the fish increases in body weight and body length (Table III). At confluence of Ravi and Chenab $\mathrm{Cr}$ concentration was higher $634.5 \mu \mathrm{g} / \mathrm{g}$ total weight of fish $H$. molitrix. Increasing order of $\mathrm{Cr}$ concentration in different organs of different fish species at sampling site of confluence of Ravi and Chenab was this muscles $(318.1 \mu \mathrm{g} / \mathrm{g})>$ liver $(221.4 \mu \mathrm{g} / \mathrm{g})>$ kidneys $(81.0 \mu \mathrm{g} / \mathrm{g})$ $>$ fats $(24.2 \mu \mathrm{g} / \mathrm{g})>$ gills $(7.1 \mu \mathrm{g} / \mathrm{g})$ Fish $H$. molitrix and $P$. atherinoides showed highest ranged as $634.5 \mu \mathrm{g} / \mathrm{g}$ and $499.0 \mu \mathrm{g} / \mathrm{g}$, respectively $\mathrm{Cr}$ concentration among other fish from confluence of Ravi and Chenab (Fig. 5). $\mathrm{Zn}$ concentration in different fish tissues of different fish 
species from confluence of Ravi and Chenab, it showed that fish C. marulius accumulated $\mathrm{Zn}$ more i.e. $510.5 \mu \mathrm{g} / \mathrm{g}$ than other fish species of same area. Increasing order of $\mathrm{Zn}$ concentration was this muscles $>$ liver $>$ fats $>$ kidneys $>$ gills ranged as $230.7 \mu \mathrm{g} / \mathrm{g}>215.7 \mu \mathrm{g} / \mathrm{g}>90.7 \mu \mathrm{g} / \mathrm{g}>9.8 \mu \mathrm{g} / \mathrm{g}$ $>4.42 \mu \mathrm{g} / \mathrm{g}$, respectively. The muscles of fish C. marulius accumulated high level $197.4 \mu \mathrm{g} / \mathrm{g}$ of $\mathrm{Cd}$ concentration. Increasing order of $\mathrm{Cd}$ levels in tissues of fish species from area of confluence of Ravi and Chenab was this muscles $>$ liver $>$ fats $>$ gills $>$ kidneys ranged as $197.4 \mu \mathrm{g} / \mathrm{g}>$ $192.5 \mu \mathrm{g} / \mathrm{g}>11.5 \mu \mathrm{g} / \mathrm{g}>11.3 \mu \mathrm{g} / \mathrm{g}>2.14 \mu \mathrm{g} / \mathrm{g}$, respectively.

There is no marked difference in cobalt concentration. C. marulius showed high levels of $\mathrm{Cd}$ and $\mathrm{Cr}$ with its body weight of $678.2 \mathrm{~g}$, length $50.5 \mathrm{~cm}$ and age 4 years. Fish $P$. atherinoides showed high level of $\mathrm{Zn}$ accumulation with its body weight of $795.0 \mathrm{~g}$, length of $61.8 \mathrm{~cm}$ and age 5years (Table III). Cr. concentration in fish liver of C. marulius and $P$. atherinoides was high ranged as $94.3 \mu \mathrm{g} / \mathrm{g}$ and $82.8 \mu \mathrm{g} / \mathrm{g}$, respectively at Chenab near Balloki site more than the fish of other selective sampling sites but in the muscles of $C$. maruliu fish concentration of $\mathrm{Cr}$ was as $81.8 \mu \mathrm{g} / \mathrm{g}$. Heavy metal $\mathrm{Cr}$ concentration in fish organs at Chenab near Balloki site was this liver $>$ muscles $>$ kidneys $>$ gills $>$ fats ranged as $94.3 \mu \mathrm{g} / \mathrm{g}>81.8 \mu \mathrm{g} / \mathrm{g}>74.9 \mu \mathrm{g} / \mathrm{g}>57.0 \mu \mathrm{g} / \mathrm{g}>54.5 \mu \mathrm{g} / \mathrm{g}$, respectively. Results of $\mathrm{Zn}$ concentration at Chenab near Balloki site showed higher concentration in fish C. nama muscle $164.4 \mu \mathrm{g} / \mathrm{g}$. Increasing order for $\mathrm{Zn}$ concentration in different fish tissues of different fish species was this muscles $>$ liver $>$ fats $>$ kidneys $>$ gills ranged as $164.4 \mu \mathrm{g} / \mathrm{g}>$ $151.7 \mu \mathrm{g} / \mathrm{g}>112.6 \mu \mathrm{g} / \mathrm{g}>22.4 \mu \mathrm{g} / \mathrm{g}>13.8 \mu \mathrm{g} / \mathrm{g}$, respectively. The Chenab near Balloki study showed higher levels of Cd in fish C. marulius $209.4 \mu \mathrm{g} / \mathrm{g}$. Fish G. chapra showed higher levels in its tissues such as Muscles $>$ fats $>$ gills $>$ kidneys ranged as $112.4 \mu \mathrm{g} / \mathrm{g}>27.6 \mu \mathrm{g} / \mathrm{g}>21.9 \mu \mathrm{g} / \mathrm{g}>$ $20.1 \mu \mathrm{g} / \mathrm{g}$, respectively. There is no mark difference in cobalt results. From Balloki $R$. rita showed higher level of $\mathrm{Zn}$ concentration that is $34.132 \mathrm{ppm}$. C.mrigala and C. nama showed high levels of $\mathrm{Cd}, \mathrm{Zn}$ and $\mathrm{Cr}$ with body

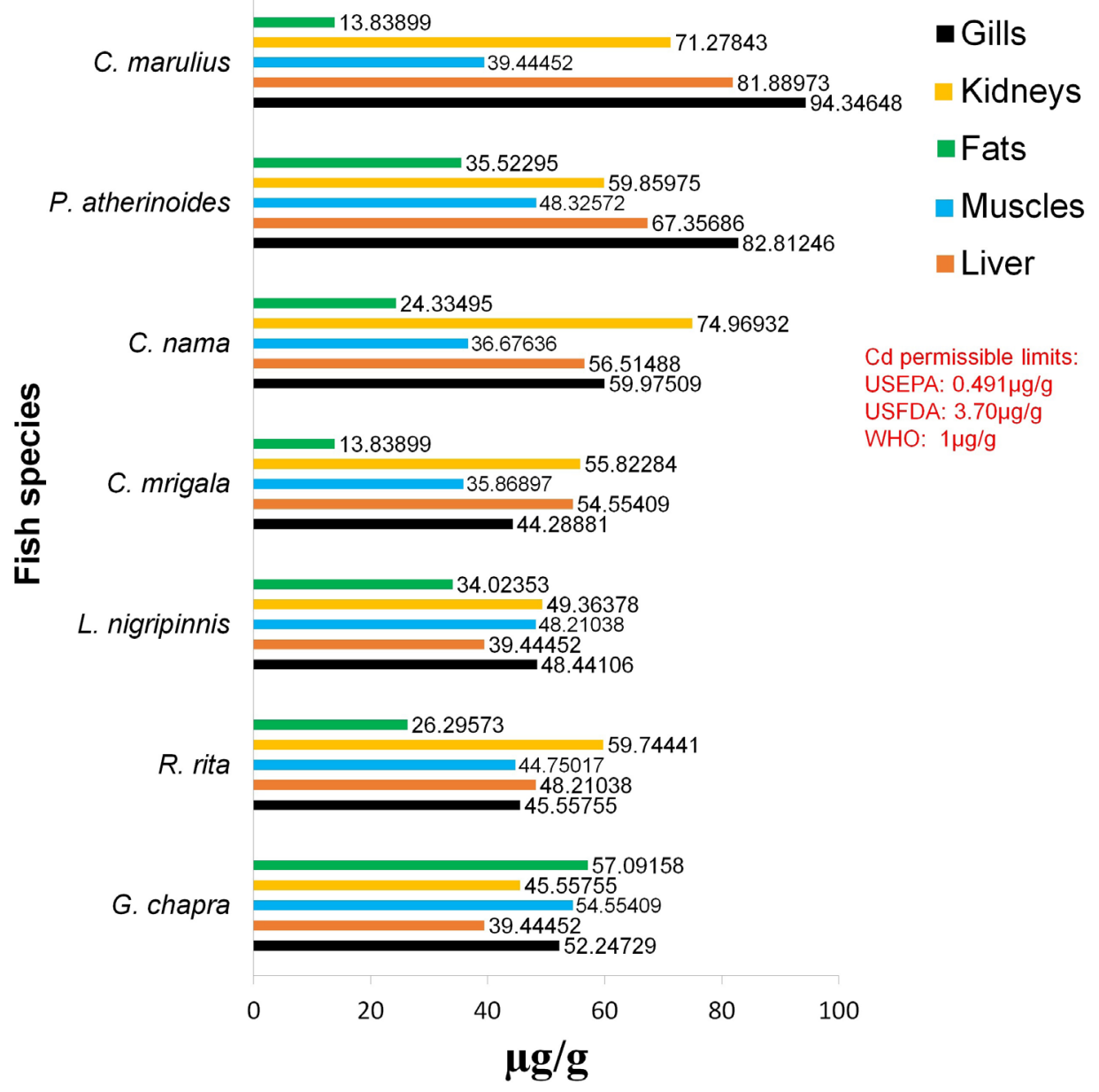

Fig. 5. $\mathrm{Cd}\left(\mu \mathrm{g} \mathrm{g}^{-1}\right)$ in different fish organs of different fish species from Baloki. 
weight $(\mathrm{g}) 456.9,440.2$, length $(\mathrm{cm}) 35.9,35.9$ and age was same in both fish species 3years, respectively (Table III). Cr concentration was high $76.05 \mu \mathrm{g} / \mathrm{g}$ in fish C.nama muscle at Balloki. Order was concentration was, muscles $>$ liver $>$ gills $>$ kidneys $>$ fats, ranged as $76.05 \mu \mathrm{g} / \mathrm{g}>75.6 \mu \mathrm{g} / \mathrm{g}>$ $43.1 \mu \mathrm{g} / \mathrm{g}>42.6 \mu \mathrm{g} / \mathrm{g}>33.9 \mu \mathrm{g} / \mathrm{g}$, respectively. In literature, the concentration $\mathrm{mg} \mathrm{L}^{-1}$ of $\mathrm{Cr}$ in Cirrhinamrigala ranged as 5.94-6.56, 6.60-7.14 in winter and summer, respectively. Above all ranges showed higher levels of $\mathrm{Cr}$ as compare to the ranges set by, USEPA permissible limit of chromium is $0.491 \mu \mathrm{g} / \mathrm{g}$, EUROPA chromium limit is $0.100 \mu \mathrm{g} / \mathrm{g}$, NEPA chromium limit $\mu \mathrm{g} / \mathrm{g}$ is 500, FAO $\mathrm{Cr}$ limit is $1 \mu \mathrm{g} / \mathrm{g}$ and $1 \mathrm{ppm}$ from international and national standard values FDA. All the findings of this study showed higher range of $\mathrm{Cd}$ in fish organs such as in muscles and in liver of different fish species from river Ravi as compare to the permissible limits of $\mathrm{Cd}$ in fish. Lowest value $167.8 \mu \mathrm{g} / \mathrm{g}$ of Cd was showed in different fish organs of different fish species of Ravi Siphon. All statistical analysis showed significant $(p<0.005)$ values of $\mathrm{Cr}$ concentration in different fish tissues of different areas. $\mathrm{Zn}$ levels in different fish organs of different fish species from Balloki, showed $\mathrm{Zn}$ concentration ranged as $96.7 \mu \mathrm{g} / \mathrm{g}>72.4 \mu \mathrm{g} / \mathrm{g}>68.4 \mu \mathrm{g} / \mathrm{g}>48.5 \mu \mathrm{g} / \mathrm{g}>39.5 \mu \mathrm{g} / \mathrm{g}$ in different fish organs such as muscles $>$ gills $>$ kidneys $>$ liver $>$ fats, respectively. Fish $C$. mrigala showed high accumulated level $307 \mu \mathrm{g} / \mathrm{g}$ among other fish of Balloki. Higher ranges of $\mathrm{Cd}$ concentration in fish C. mrigala $545.3 \mu \mathrm{g} / \mathrm{g}$ and in its organs such as in muscles $>$ liver $>$ fats $>$ gills $>$ kidneys ranged as $255.9 \mu \mathrm{g} / \mathrm{g}>145.8 \mu \mathrm{g} / \mathrm{g}>$ $76.9 \mu \mathrm{g} / \mathrm{g}>37.5 \mu \mathrm{g} / \mathrm{g}>37.4 \mu \mathrm{g} / \mathrm{g}$, respectively. As compared to other tissues of different fish species of Balloki, Cd concentration increasing order was, muscles $>$ liver $>$ fats $>$ kidneys $>$ gills ranged as $225.9 \mu \mathrm{g} / \mathrm{g}>145.8 \mu \mathrm{g} / \mathrm{g}>76.9 \mu \mathrm{g} / \mathrm{g}$ $>42.3 \mu \mathrm{g} / \mathrm{g}>37.5 \mu \mathrm{g} / \mathrm{g}$, respectively. Cd has high potential for bioaccumulation in fish organs. Highest $\mathrm{Cd}$ ranges were found in different fish species from confluence of Ravi and Chenab, fish organs such as liver and muscles were highly contaminated from $\mathrm{Cd}$ but in Balloki pond water fish muscles and fats are highly contaminated (Fig. 3). In our results, the observed concentrations for $\mathrm{Cd}$ found to be in high ranges as compared to the permissible limits set by different organizations (FAO/WHO, 1989; USEPA, 1989). Observed values of Co-concentrations in different organs of fish species were below the standard limits although the detectable and published limits of Co. in fish were from 0.04 $-0.26 \mathrm{mg} / \mathrm{kg}$ and $0.05-0.28 \mathrm{mg} / \mathrm{kg}$ (Yilmaz, 2009). Fish fats showed least concentrations than all the body organs. Liver and muscles showed higher concentration of metals than all the body organs. Muscle is the main body organ of fish which is eaten by humans in Pakistan, liver and kidneys are not edible but in world many countries like China eat other fish organs such as eyes, liver, gills and kidneys etc. Kidney is the main organ for metal detoxification. In kidney, significant amounts of metals were collected (Mustafa et al., 2008). The results clearly demonstrate that the fish of river Ravi faces metal pollution in particular areas for $\mathrm{Zn}$, $\mathrm{Cd}, \mathrm{Co}$ and $\mathrm{Cr}$. $\mathrm{Zn}$ and $\mathrm{Cd}$ are high in concentration present in river Ravi water.

\section{CONCLUSION}

Herein, fish species including C. marulius, C. nama, H. molitrix and C. mrigala showed high levels of metal accumulations in their body tissues, measurement difference in body weight and length was showed in same fish species from selective study areas. Higher metal concentrations have resulted in the decrease of fish species found in Ravi during the recent years. Further studies are required to explore the phenomenon in detail.

\section{ACKNOWLEDGMENTS}

Authors would like to thank the staff members of 'Wild Life Balloki' and Department of Environmental Sciences, Kinnaird College, Lahore for their help. Prof. Abdul Rauf Shakoori was consultant to the research project.

Conflict of Interest

The authors declare no conflict of interests.

\section{REFERENCES}

Ahmed, K., Baki, M.A., Kundu, G.K., Islam, S. and Islam, M., 2016. Human health risks from heavy metals in fish of Buriganga River, Bangladesh. Springerplus, 5: 1697. https://doi.org/10.1186/s40064-016-3357-0

Al-Majed, N.B., Majed, A.S., Rajab, W.A., Farhan, M.S. and Iqbal, A.R., 1998. Levels of trace metals and hydrocarbons in fish from Ropme Sea Area Offshore. Terra Scientific Publishing Company, Tokyo. pp. 257-279.

Al-Ghanim, K.A., Mahboob, S., Seemab, S., Sultana, S., Sultana, T., Al-Misned, F. and Ahmed, Z., 2016. Monitoring of trace metals in tissues of Wallago attu (lanchi) from the Indus River as an indicator of environmental pollution. Saudi J. biol. Sci., 23: 7278. https://doi.org/10.1016/j.sjbs.2015.03.012

Al-Weher, S.M., 2008. Levels of heavy metal Cd, Cu and $\mathrm{Zn}$ in three fish species collected from the Northern Jordan Valley. Jordan J. biol. Sci., 1: 41-46.

Arther, S., 2015. Identification and detection of heavy metals in selected water samples containing micro flora and micro fauna. Master's thesis, Kinnaird 
College for Women Lahore Punjab Pakistan.

Emmanuel, J., Joshua, G. and Shams, S.B., 2012. Comparative study of ecological conditions of four wetlands of punjab using macro-invertebrates as bio-indicators. J. Anim. Pl. Sci., 22: 1018-7081.

FAO/WHO, 1989. National Research Council Recommended Dietary Allowances (10th ed). National Academy Press, Washington, DC

Hashim, R., Song, T.H., Muslim, N.Z.M. and Yen, T.P., 2014. Determination of heavy metal levels in fishes from the lower reach of the kelantan river, Kelantan, Malaysia. Trop. Life Sci. Res., 25 21. 25(2):21.

Hayat, S., Javed, M. and Razzaq, S., 2007. Growth performance of metal stressed major carps viz. Catla catla, Labeo rohita and Cirrhina mrigala reared under semi-intensive culture system. Pak. Vet. J., 27: 8-12.

Hayder, S., Haider, H., Nadeem, O., Hussain, G. and Zahra, S., 2015. Proposed model for wastewater treatment in Lahore using constructed wetlands. $J$. Faculty Eng. Technol., 22: 07-17

Javed, M., 2006. Studies on metal contamination levels in planktonic and their role as biological indicator of water pollution in the river Ravi. Pak. J. biol. Sci., 9: 313-317. https://doi.org/10.3923/pjbs.2006.313.317

Karadede-Akin, H. and Unlu, E., 2007. Heavy metal concentrations in water, sediments, fish and some benthic organisms from Tigris River, Turkey. Environ. Monit. Assess. 131: 323-337. https://doi. org/10.1007/s10661-006-9478-0

Khan, M., 2011. pH of soil and plant nutrient: The case. Gardening Pakistan Forum.

Kuz'mina, V.V., 2011. The influence of zinc and copper on the latency period for feeding and the food uptake in common carp, Cyprinuscarpio. L. Aquat. Toxicol. 102: 73-78. https://doi. org/10.1016/j.aquatox.2010.12.018

Mahboob, S., Al-Balawi, H.F., Al-Misned, F., AlQuraishy, S. and Ahmad, Z., 2014. Tissue metal distribution and risk assessment for important fish species from Saudi Arabia. Bull. environ. Contam. Toxicol., 92:61-66. https://doi.org/10.1007/s00128013-1139-8

Mahboob, S., Kausar, S., Jabeen, F., Sultana, S., Sultana, T., AlGhanim, K.A., Hussain, B., Al-Misned, F. and Ahmed, Z., 2016. Effect of heavy metals on liver, kidney, gills and muscles of Cyprinus carpio and Wallago attu inhabited in the Indus. Human Anim. Hlth., 59: 16150275. https://doi.org/10.1590/16784324-2016150275

Milanov, D.R., Krstic, P.M., Markovic, V.R., Jovanovic,
A.D., Baltić, M.B., Ivanovic, S.J., Jovetić, M. and Baltic, Z.M., 2016. Analysis of heavy Metals concentration in tissues of three different fish species included in human diet from Danube River. Acta Vet., 66: 89-102. https://doi.org/10.1515/acve2016-0007

Mirza, M.R. and Sandhu, I., 2007. Fishes of the Punjab, Pakistan. Polymer Publications: Pakistan.

Mustafa, T., Aysun, T. and Yalcin, T., 2008. Metal contaminations in five fish species from Black, Marmara, Aegean and Mediterranean seas, Turkey. J. Chil. Chem. Soc., 53: 1. https://doi.org/10.4067/ S0717-97072008000100021

Papagiannis, I., Kagalou, I., Leonardos, J., Petridis, D. and Kalfakaou, V., 2004. Copper and zinc in four freshwater fish species from Lake Pamvotis (Greece). Environ. Int., 30: 357-362.

Rauf, A., Javed, M., Ubaidullah, M., Abdullah, S. 2009. Heavy Metal levels in three major carps (Catlacatla, Labeorohita, Cirrhinamrigala) from the river Ravi Pakistan. Pak. Vet. J., 29: 24-26. https://doi. org/10.1016/j.envint.2003.08.002

Rauf, A. and Javed, M., 2007. Copper toxicity of water and plankton in the River Ravi, Pakistan. Int. J. Agric. Biol., 9: 771-774.

Sfakianakis, D.G., Kentouri, P.M. and Tsatsakis, A.M., 2015. Effect of heavy Metals on fish larvae deformities: A review. Environ. Res. 137: 246-255. https://doi.org/10.1016/j.envres.2014.12.014

Sthanadar, I.A., Begum, B., Sthanadar, A.A., Nasar, M.J., Ahmad, I., Zahid, M., Muhammad, A. and Ullah, S., 2015. Bioaccumulation of heavy Metals in intestine of Mulley (Wallago attu, Bloch and Schneider, 1801): A case study of Kalpani River at District Nowshera Khyber Pakhtunkhwa Pakistan. $J$. Biol. environ. Sci., 6: 74-80.

Twari-Fufeyin, P. and Ekaye, S.A., 2007. Fish species diversity as indicator of pollution in Ikpoba river, Benin City, Nigeria. Rev. Fish. Biol. Fish., 17: 2130. https://doi.org/10.1007/s11160-006-9015-9

Ukoha, P.O., Ekere, N.R., Udeogu U.V. and Agbazue, V.E., 2014. Potential health risk assessment of heavy Metals [Cd, $\mathrm{Cu}$ and $\mathrm{Fe}]$ concentrations in some imported frozen fish species consumed in Nigeria. Int. J. chem. Sci., 12: 366-374.

USEPA (United States Environmental Protection Agency), 1989. Office of Water Regulations and Standard: Guidance manual for assessing human health risks from chemically contaminated, fish and shellfish. U.S. Environmental Protection Agency, Washington, DC; EPA-503/8-89-002. 
Vosylien, M.Z. and Jankaite, A., 2006. Effect of heavy Metal model mixture on rainbow trout biological parameters. Ekologija, 4: 12-17.

Yilmaz, F., 2009. The comparison of heavy metal concentrations $(\mathrm{Cd}, \mathrm{Cu}, \mathrm{Mn}, \mathrm{Pb}$, and $\mathrm{Zn})$ in tissues of three economically important fish (Anguilla anguilla, Mugil cephalus and Oreochromis niloticus) inhabiting Koycegiz Lake-Mugla (Turkey). Turkish J. Sci. Technol., 4: 7-15. 